\title{
Manoj Das: An Incredible Bridge between Literature and Philosophy
}

\author{
Dr. Santosh Kumar Nayak \\ Assistant Professor, P. G. Department of Odia, F. M. Autonomous College, Balasore, Odisha, India
}

\begin{abstract}
How to cite this paper: Dr. Santosh Kumar Nayak "Manoj Das: An Incredible Bridge between Literature and Philosophy" Published in International Journal of Trend in Scientific Research and Development (ijtsrd), ISSN: 24566470, Volume-3 | Issue-4, June 2019, pp.605-613, URL: https://www.ijtsrd.c om/papers/ijtsrd23 866.pdf

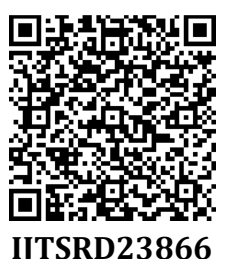

Copyright (C) 2019 by author(s) and International Journal of Trend in Scientific Research and Development Journal. This is an Open Access article distributed under the terms of the Creative Commons

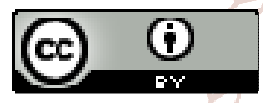
Attribution License (CC BY 4.0) (http://creativecommons.org/licenses/ by/4.0)

\section{Introduction}

The works of Manoj Das (b.1934), one of the Padmashree awardees of India, the great son of the soil of Balasore, Odisha, act as an aqueduct between literature and philosophy. It is hard to separate philosophy from literature and interestingly there are some litterateurs who are embedded in the matrix of philosophy but are dressed with literature. Shri Das is certainly one of them. The beams of their thoughts are refracted through the prism of literature but photons of the beams are philosophical by nature. For example, a tree may be a piece of literature for its leaves, branches, woods, nests on it, and also for many more creatures those who live in it. But basically, its development is based on absorption, transportation and photosynthesis and other physiological and physiochemical processes through different systems of the tree. Again, it depends upon various factors, both internal and external. This is purely logical. But the logics, but the philosophy how can we differentiate between Xerophytes, Pteridophytes, Hydrophytes, Mesophytes, Halophytes and Hygrophytes? How can we differentiate between ever green plants and deciduous plants? Similarly, the germination factors of the literatures of Shri Das are explicitly logical as well as philosophical. The thoughts of his literature take their origin from the thallus (thalli) of philosophy. He has made fine experiments in prose (both fiction and non-fiction) and poetry as well. In each case, he has been proved to be more philosophical than literary. One can easily discover the plurality of truth from the texts and contexts of his literature.

\section{Philosophy, Literature and Das}

Philosophy is really a multi-dexterous term with numerous dimensions of its own with respect to various other disciplines, matters, time and conditions. John Dewey has rightly said in this regard that philosophy is not a panacea for the problems of men, but it is that which emerges out of the methods employed by them to solve their problems. Pierre Hadot's statement regarding philosophy is quite contextual here. He said, "Ancient philosophy proposed to mankind an art of living. By contrast, modern philosophy appears above all as the construction of a technical jargon reserved for specialists." In case of Manoj Das we see both the things. Some see some of the layers of his literature (fiction and non-fiction) and some see the rest layers as per own depth, concentration and capacity. His literature is just like an onion. The more one goes into penetrating inside the more s/he sees, the more s/he discovers. We can remember Julia Kristeva, Roland Barth and Reader Response Critics here in this regard. As per Johann George Hamann's definition the attempts of Shri Das in his literature clearly shows his thirst for the ultimate truth, virtue and those clearly reflect his heroic and pious spirit with an ultimate ambition to conquer over all the lies and vices. Here, he has taken the help of partial-lies under the guise of literature in order to detoxify and eradicate the evil things in man and its artificial environment. From the view points of Kierkegaard we must see as well as evaluate his (Das') literature. Though Kierkegaard has said that the crucial thing is to find a truth which is fit to one's own life and a truth for self or to find 
such an idea in which he lives or will live or die and though he is not in the support of going with an objective truth or constructing a world where he never lives in still Manoj Das has recommended for both the things, both the truths and both the ideas. He has gone for a personal reality as well as a general or objective reality in his literary attempts.

One day Jane Yolen said, "Literature is a textually transmitted disease, normally contracted in childhood." In case of Shri Das we can certainly say that he has been affected by his family, the then socio-cultural environment, the economic state and socio-political scenarios of the time, especially of his childhood memory. He has gained and inherited the spirit of the time and the zest of the society and values of the cultured in which he lived in. Really, a writer lives in his works as he does in the socio-cultural and sociopolitical matrix of his own time. Manoj Das has given the refracted resolutions of the pre-independence society and environments as well as some experiences of the postindependence period and the societal pictures of Odisha in his short stories and memoirs. In Das' literature we see rigorous dialogues between literature and philosophy. In one hand where there is a sense of aesthetics there in other hand there is a sense of criticism or critical analysis which is itself philosophical in nature. Many of the philosophers and literary theorists do strongly believe that literature and philosophy converge in many occasions. Therefore it is said that great literature is often philosophical and great philosophy is often literature. Without the charm of literature one cannot produce a better and interesting philosophy and vice versa. Lanier Anderson, the professor of philosophy at Stanford University has made several investigations which lay the foundation of relevance between literature and philosophy with an ambition to collapse the boundary between the disciples. Though philosophy revolves round truth, intellect, reason and literal use of language and literature focuses on fiction, fables and metaphorical language embedded in emotions still these two have a relationship of milk and water and hence are inseparable from each other. We can take the instances of Plato's dialogues and Borges's short story "Pierre Menard, Author del Quixote" for examining the notion of authorship and also we can take here the paradigm of Albert Camus' "The Plague" for examining the notion of freedom. Anderson argues on the basis $f$ the above cited examples that there are distinctively literary methods to pursue philosophy. In the case of Sri Das we can say that none of his characters (who are submerged in the ocean of emotion) is the "mouthpiece" of the author. It is evident that from the expressions and behaviours of the involved characters of his fictions the reader (much involved and also not involved one) must reckon for themselves who is right and who is wrong with sufficient reasons at his own fist. We can ponder over the suggestions of Das' literature over 'Natural Language', 'Notion of Narratives', 'Narrative Impulse and Cultural Norms' and 'The Notion of Fictitious Basis and Readers' Emotional Reaction'. For example, Sartre's Nausea suggests that having 'narrative structure' in one's life is highly significant in condensing one's 'sense of self'. It is a part of our biological programme/ instincts as well as our cultural norms we live in. And if literature is totally fictitious and a reader knows it, then why should s/he react to that? Why should one cry for that little girl of 'A Letter from the Last Spring' or why should one be so emotional for that little girl Laxmi in 'Laxmi's Adventure'? This is nothing but the basement of philosophical theories of emotion, empathy and imagination. A fictitious (unreal) stimulus produces a real response (laughter, tear, anger etcetera). If the character is false and the reader is true and the reader knows all the truths about the false existence of the characters, then why does $\mathrm{s}$ /he produces true response in terms of fear, anger, tear and laughter etcetera? This clearly shows the closeness of philosophy and literature and breaks the boundaries and hindrances in between. We can take some instances of philosophers who have been regarded as litterateurs for their style and thematic treatment. Nietzsche and Wittgenstein write in a dramatic "aphoristic" style. Some great attempts of philosophy, like Plato's Symposium, are also significant landmarks of literature. Similarly, we can take the instance of Albert Camus' 'The Myth of Sisyphus', Shakespeare's Romeo and Juliet and Sartre's many works. Similarly, the Anglophone philosophers who usually write dry and pedantic prose, sometime also write dialogues. Similarly, Manoj Das' 'Amruta Phala' (The Divine Fruit) is more philosophical than a piece of literature. Many of his essays, memoires and prose are strictly philosophical. Somewhere he is sunk in the philosophy of Aurobind and somewhere in Hinduism and also somewhere in his own.

In each and every literature we face this thing. But in case of Manoj Das we face some special events and characters in terms of reader's reality. Reader's Reality is another kind of reality that we face and experience as a reader which is quite different and special to that of the truth in general. Many of the characters of Shri Das have been chosen from the day-today lives of us. The way he has narrated in his works, make them closer and truer to the readers than others'. He directly arrests the archetypal nucleus of a reader through his narration and forces to be tames by resonance of his narrative techniques.

Each and every photon of the resonance of Das' literature (both in prose and poetry, fiction and non-fiction) deals with the most fundamental concepts and doctrines of human thoughts, actions and reality. It is of course his own curiosity and exercise of his innate quality and intelligence from head, heart and soul. Perhaps these three dimensions of his attempts force the readers to adhere themselves to the contexts and contents (messages) of his literature. In most of his prose like travelogues and essays we encounter a keen and acute quest for the view of the world and human existence in it. We see some rational enquiries in much critical and logical way. The motto underneath these enquiries is only to attain the real wisdom for the sake of inner truth and reality of life. We see various concrete actions in our day-to-day life but Das has given a critical reflection of those concrete actions. In this way we can say that Das' literature is the meta-reflection (reflection of the reflections) on concrete actions in and around us. The greatest proof of his philosophical basis is his modus operandi, which should be there in every beat, in each and every cell of humanities (here literature). This also says that Shri Das' literature has that much of capacity to save the drowning and down falling humanity and human race. Means, it has the potency to act like an anti-nuclear weapon for the sake of entire human race. We can, thus, firmly say with regard to his literature that those are persistent attempts to gain insight about the world within and around us. A series of systematic reflections has been seen in his each and every literary attempt and thus these are worth saying philosophical. In a very slow and modest way, Manoj Das' literary attempts have tried to spill the beans of 
expectation, reason, causation, consciousness, free will and space in the hearts of his reader with a special reference to this abstract world. And of course, both the worlds; the world within and the world around us are symbiotic and interrelated to each other. And the inner or the affected world is much powerful and with adequate potential to bring necessary changes in the outer one. Hence, Das' has always focused the inner world than that of the outer one in his literary attempts. It is because one can change the outer world simultaneously if s/she is fully determined with the inner world although it is affected by the outer one earlier. Can we forget his short-stories in this regard? Can we forget the human emotions he used in those as the weapon to heel the human wounds? Can we forget his doctrines and expeditions made to the vast world of knowledge and human existence and motifs in his essays (especially in 'Bipulaacha Prithvi' which means Vast is the World)?

When one talks about the literature of the literature of Manoj Das, s/he automatically gets connected with the literature of the post-independence literature (society) of Odisha as well as India. This is the period where literature has gone across the sea in many respect spontaneously and frequently. The eminent poet and critic Sitakanta Mahapatra says in this regard that, the literature of this period 'connects everything to everything'. Further he says that it is quite impossible and difficult for one "to go into any detailed analysis of either individual genre of writing or individual authors" (Mohapatra, 1977, p. 728) in a short survey of such a complex and multifold literary patch. Further Mohapatra adds,

"At the outset one may venture one or two general observations. Immediately after independence there was quite a bit of idealism, euphoria and enthusiasm in the air: perhaps a sense of release as well." (728)

In the stories and fictions of Sri Das there lies a deep sense of humanism, existentialism, the human miseries and fate and an honest attempt to make out the multiplex human destiny underneath the cynical visage. Mahapatra has very beautifully marked the human destiny sketched by Das in his 'Mayor of Madhubana', a beautiful short-story on life. He, therefore from a critical perspective, says-

"There is no running away from this disturbing awareness of our cruel destiny. Life, as Camus pointed out, begins on the outside of despair. The commitment, however, is ultimately to life, the difficult job of living and finding some meaning and significance for oneself like the Mayor of Madhubana in Manoj Das who discovers maturity of understanding only through a terrible dawn of the sense of helplessness."(735)

The writer is quite dissatisfied with the various societal outputs, although those are according to the law of nature and under the cruel rule of creation and devastation (wear and tear). Thus, he either projects a character/ protagonist against these things or projects the protagonist as a serious victim of those unfair and unwanted things in order to gain the readers' consciousness or readers' attention over the events. Manoj Das has done the second one very tactfully in most of his fictions and essays. This is the secret of his successful art of story-telling and his specialty as well. Das has that art amply in him to arrest the attention of his readers. He does many similar psychological treatments like Fakir Mohan Senapati, the father of modern Odia short-story and social-fiction. Like Senapati, Das has a philosophical quest in his work. Those were ethically rich in case of Senapati's literature. The major treatments of Senapati were severe irony, serious and ample satire, use of tragedy, selective terms pricking the human psychology of the target group and treatment of destiny with man. One can firmly say that Das is a perfect heir of Senapati who has taken almost all of the aforesaid qualities by the process of literary inheritance. But the literature of Senapati was embedded in the matrix of ethics whereas the literature of Das is submerged in the matrix of serious philosophy. We see Richard Bernstein's 'rage against reason' has a keen relationship with the ideas and philosophy of Jean-Paul Sartre called existentialism. This complex philosophy has been adopted by many of the modern poets and novelists and story-tellers as Das has done in some cases.

Manoj Das has been simpler and philosophical day by day. Here, we can set his own words in this regard:

"Since, I have translated the stories myself, I have avoided being literaral, I have slightly altered the titles of some of them in their English version, for example "Bihanga" (Birds) to "Birds at Twilight" and "Pratyabartan" (Return) to "Return of the Native"." (Das, 1995: p. v)

In the preface to the book 'Mystery of the Missing Cap and Other Stories' (1995) Das has been more 'particular'. In the Odia version of his stories, he is a little more subjective with his broad captions (broad in terms of sense). Particularly, this book 'Manoj Dasnka Kathaa 0 Kaahaani' was published in 1971 and was awarded in 1972 by Sahitya Akademi. And in the other hand while translating those Odia stories in 1995 after 24-25 years he has been much reader-conscious and more objective by that time. To be reader-conscious and to be objective and particular indicates his philosophical and psychological consciousness which have also been disseminated in his words through the time being.

\section{Das' Literary Context versus Various Philosophy}

We see Kantian treatment or Kantian philosophy in the literary contexts of Manoj Das. Similarly, we encounter the philosophical perspectives of Martin Heidegger. We can recall here the treatment of Heidegger with the Kantian perspectives and speculations regarding 'metaphysics'. Man and metaphysics are the two important subjects related to each other in a very special way with special circumstances in special time space and context (situation). In some of the stories of Sri Das we encounter Kant walking and talking on the pavements of the plots and in some of the stories and novels we face Heidegger in an anchoring gesture. As a story teller Das has gone into the faculty of 'transcendental imagination' with a 'theory of experience'.

"Heidegger fights against the assumption that Kant's essential goal consisted in grounding metaphysics on epistemology. He thinks that Kant's entire work is a doctrine amounting to an ontology. The Critique leads to one fundamental question, i.e., the question of man. Kant was seen as the theoretician of a mathematico-physical epistemology. But Kant, according to Heidegger, never meant to offer a theory of physical sciences. What he means to indicate was that the problem as upheld by Kant was not a problem of epistemology but the problem of metaphysics as ontology."(Bandyopadhyaya, 2005: p. 92)

We can recall the Kantian views about Prolegomene, 'the problem of the possibility of metaphysica generalis'. Man is not at all a cognizing being; he knows everything, chooses 
everything, acts as per the need and walks with the lump of the hopes. In some situations of Das' plots of his fictions we perceive the present as "the offspring of future and past."(Solomon, 1972: p. 223) This is nothing but the philosophy of R.C Solomon. As per the philosophical views of Martin Heidegger we see those three fundamental aspects of human being namely; 'existentiality', 'facticity' and 'forfeiture'(Verfallen). In some of his stories and especially in his novels like Amruta Phala (The Divine Fruit/ The Fruit of Ambrossia) and Aakaashara Isaaraa (Allusion of Sky) etcetera Manoj Das has made serious deals with the serious and significant existential subjects like 'existentialism', 'metaphysics', 'metaphysics of man', Dasein (according to Heidegger's interpretation) and finitude etcetera. Characters like Baladev are completely philosophical and are sketched for the sake of philosophy. The philosophical maters like Dasein as Existenz i.e. as possibility or transcendence, the relation between 'Dasein and Death', that is as 'possibility', as a 'possible being', a 'being towards death' and the facts and phenomena between 'Dasein' and 'finitude' have been well revealed and experimented in between the longitudes and latitudes of his literary plots. Being and Time, the significant book of Heidegger, has many serious impacts on the literary context and sometimes the impact has been prominent in the texts (textual arrangement/design) Professor Das' literature. The literature of Sri Das has a deal with the blind destiny with a combination of artistic excellence.

The litterateur inside Sri Das is always vigilant within and around him. This personality of Das is quite rare, surprising and unique. He lives many lives as an author or as a novelist or story teller. But the matter of fact in between is his binary life. He synchronously lives two major personalities: one is his Creative Persona and other is his Conscious Persona. One gets lost in the lap of human emotions, anger, phobia, societal events, love, affection and things around and inside us but the other one at the same time remains conscious and vigilant. One changes its own emotions according to the caste, creed, culture, community, colour, gender, age and environment etcetera of his character(s), plot(s) and theme(s) but the other at the same time remains unchanged and unbiased. In fact, the second one controls the first one as per necessity. This is the reason for which Manoj Das sounds much philosophical and logical than other. And this particular quality of binary personality is very rare and hardly seen in other contemporary writers of Odisha. We can see that in Laxmi's Adventure as well as in 'A Letter from the Last Spring', or in the various plots and subplots of 'The Divine Fruit' or 'In the Search of the Last Tantric' (the newly published novel in 2018). To be lost in the lap of Nature is a common experience of the litterateurs but to be conscious and vigilant at the same time is quite different thing. Some of the captions of the short stories by Manoj Das which are philosophically conscious are: 1. Tragedy, A Song for Sunday, Justice from the Hill, The Anatomy of a Tragedy, The Candle, A Letter from the Last Spring, The Midnight, The Discovery, The Night and the Tiger Came, The Rest of the World, Smiles And..., Of Man and Monkey, The Third Person, From Roy Sing's Diary, The Last I heard to Them, Time for a Style, The Intimate Demon, Return of the Native and Birds at Twilight etcetera.

Similarly, the contexts or the themes of many other short stories are really interesting and philosophical at the same time. Manoj was a mature writer from his early days. One of the proofs is his winning of the prestigious Sahitya Akademi award in his very young age in 1972. His Samudrara Khyudhaa (The Hunger of the Sea, 1950), Bissa Kanyaa ra Kaahaanee (The Story of the Poison-Girl, 1955), Sesha Basantara Chithi (The Letter of the End-Spring, 1965), Aabu Purussa o Anyaanya Kaahaanee (Abu Purusha and Other stories, 1965), Manoj Das nka Kathaa O Kaahaanee (The Stories and Tales of Manoj Das, 1971), Laxmira Abhisaara (The Tryst of Lakshmi, 1974), Dhumraabha Diganta (The Hazy Horizon, 1977), Manoj Pancha Binshati (Twenty-Five of Manoj, 1983), Abolkaraa Kaahaani (The Tales of Disobedient Man, 1996) story collections are fabulous and rich in philosophy, cultural values, interesting joints and twists of human psychology, societal psychology, values and evolution of human mind, values and ethics, our great and proud moments of history and many more. In a nut shell, his shortstories are like the nut-shells where history, philosophy, politics, psychology, society, and changing values of all these things with respect to the changing trends of time are compactly packed. Some of his famous and significant stories are: 'Samudrara Kshyudhaa' (The Hunger of the Sea), 'Aaranyaka'(Beastly), 'Jaajaabara Putra ra Kaahaanee'(The Story of the Vagrant Son), 'Rai Baahadur nka Nisha' (The Moustache of Rai Bahadur), 'Antaranga Daanaba' (The Intimate Giant), 'Doora Nirjanara Swara' (The Voice of the Distant Loneliness), 'Adrusta Muhoorta' (The Unseen Moment), 'Abashissta Pruthivee' (The Rest of the World), 'Ota' (The Camel), 'Apahruta Topira Rahasya' (The Mystery of the Missing Cap), 'Tryst of Laxmi'/ 'Laxmi's Adventure', 'A Farewell to the Lady Ghost', 'The Submerged Valley' and 'The Letter of the Rest-Spring'. These stories are submerged in the intense solution of history, myth, philosophy, psychology, culture, social values, human wills and possibilities and are alert at the same time to the other end of naked reality. This is the specialty of Das for bearing this dual personality while writing which may also be encoded as his readerconsciousness and time (the past, the present and also the future one) consciousness synchronously.

Manoj Das has proved his talents in story telling in a very short period of time. While he started writing stories in the fifties, he got excellence and prominence in the sixties just in between a decade. Now, in India Manoj Das is a substantial and exemplary short-story writer today. He has much significance in his stories and fictions as well in terms of theme and style.

"His stories had an intellectual frame, psychological attitudes and provided good insight into contemporary life. In addition, he had an implicit spiritual enquiry as an integral part of his stories, and often put emphasis on the country's past tradition, a good example being his continuous echoes from Bishnu Sharma and Panchatantra. Surendra Mohanty refers to this aspect when he points out that Manoj does not write stories but tells tales. In fact, almost all the components of Manoj's thematic structure such as , humanistic attitude, spirituality, mystic elements, and spirit of compassion, are suitably adjusted with his choice of language, stylistic variations, and a relaxed, intimate tone- as if , somebody sitti9ng close to us is narrating a tale with aplomb, that pleases him as well as the listeners." (Mohanty, 2006: p. 611-12)

Manoj Das has his own style for which he has earned this kind of unbeatable fame. He is as special in his fictions as in non-fiction prose. In the very first half of his literary life he was well familiar as a short-story writer. In the later half he 
started writing novels. And surprisingly he got immense and outstanding success in that field. His non-fiction prose is the living philosophy and the commentary of life. Another great philosophical writer, the great litterateur, C.R. Das says-

"He has a style all his own, direct yet full of sarcastic nuances. His choice of words perfectly serves his style and his intention. [...] One of the story collections of Manoj Das at his early phase is Aranyaka which deals with the blatant irrational in man. He has produced innumerable fables for children mainly in English language and some of them are also available in Oriya. One of his short story collections has been named 'Fables and Fantasies for Adults'. It sometimes appears that most of Manoj Das's stories read very appropriately as fables for adults. Starting with the irrational in man and then adding a few doses of cynicism of the benevolent type to his total attitude those for whom he writes, he seems to have ended up with looking at man as an adult who can be satisfied with fables. An enception in the ocean of stories Manoj Das to his credit is the one captioned 'Lakshmira Abhisara' where there is the least of the salvationistic cynical element which is so typical with Manoj Das. After everything has been said and delivered, it is not the cynicism of the Salvationist that will save mankind; it may at best make man happily reconciled to his lot, in the meanwhile taking a sort of masochistic pleasure at his own misery and helplessness. Masochism is no remedy for men in the present predicament, even when it is being prescribed by good men in the form of well-knit fables and stories."(1982: p. 262-63)

Manoj das has various deals with philosophy directly or indirectly. Sometimes he has made commentarye on philosophical topics and sometime he has sketched stories with the frame of philosophy. Most of his novels like 'Amruta Phala' (The Divine Fruit) and 'Aakaashara Isaaraa' are embedded in highly philosophical matrix.

\section{Manoj Das through the Prism of Meta-criticism}

Manoj Das is really a versatile genius. He is not only a successful story teller but also a magnificent novelist, poet with adequate lucidity and strength, a successful prosewriter, radiant editor and above all a brilliant critic and compiler of texts and contexts. It will be too lengthy if one traces the beauty and his philosophical deeps in each and every attempt in all of his works in this category. Therefore, Professor J.M. Mohanty has rightly said, “[...] he travels all over the world, and writes stories, novels, travelogue, essays, belles letters etc. with equal competence." (2006: p. 611) We can take for an instance of his introduction to the compiled works of Sri Aurobindo. He has scanned almost all the genres of Aurobindo and his life synchronously on the basis of which he has spoken a few words there in his intro. But it is true that a man sees from the core of his own retina. The words of Victor Hugo echoes here in this context particularly. Really, every writer is present in his every work, in his/her every attempt. How Das can be escaped from this rule? Yes, of course he is present in his commentary, his poetry and expressions of his experiences apart from his fictional work. The way he looks a thing makes his perspectives crystal-clear. It dictates that Sri Das is philosophical from inside so he is unfit to be free from the pulchritude and femme fatale of philosophy in his statement. In fact, it is one of his potencies and specialties. In the very first paragraph Das has asked about an interesting part of Aurobindo's literature (works). That is, surprisingly, not about his work. It is a treatment of the matter with a method of induction. One can easily understand what he wants to say and what he wants to emphasize from the following few lines:

"Every life-sketch is an account of external events in which the subject participated or which were caused by the subject. If the subject lived a meaningful and conscious inner life, it might or might not be reflected on the recoded events of life. But there could be some who lived an inner life too profound to be entirely reflected on the events that centered on them or even on their own deeds. That is why there is nothing surprising in what Sri Aurobindo told a scholar who proposed to write a biography- that no one could write about his life because it had not been in the surface for men to see." (Das (ed.), 1995: p. i)

A writer or critic just looks into the works of a man. One gives importance on the works which is visible. But in fact that is not the truth. It is the invisible life/ the invisible world of the author which rigorously and continuously goes on affecting the visible one. Hence, Sri Das has given his utmost importance on the inner life, his attitudes and perspectives of Sri Aurobindo in order to give remarks and views on his works. He has given a close look into his visible life too. What Kristeva says in this regard may be remembered. One is compelled to think like the class s/he lives in.

"[W]e are not dealing with a cursory history that strings together sociopolitical events but the history that Nietzsche called monumental history: in history of mentalities, mutations in man's relationship to meaning." (Kristeva, 2000: p. 195)

This clearly says that Aurobindo's wrings are the product of his life. But Das has given more emphasis on the inner life to which Sri Aurobindo lived in and he believes that it is the matter from which the inner resonance of sense is disseminated which later on constitutes the crystals of literature. Further, Das says that bases on his external life of first forty seven years 'an absorbing volume could be written' apart from his later half of life, the divine one. He further says about the personal doctrine and credence of Sri Aurobindo's father Dr. K. D. Ghose about the 'values of life' (Das(ed.), 1995: p. i) apart from his 'faith in the Western, the English, the English in particular' (Ibid). How logical and scientific the author is! One can mark from the following observation. Manoj Das has pointed the identity of his grandfather (father of her mother Swarnalata Devi Rajnarayan Bose) that he was a 'Rishi and described by some as "the Grandfather of Indian Nationalism"[...] later to be hailed as "the Prophet of Indian Nationalism"'.(Ibid) he had no direct impact on the child Aurobindo but he might have been some genetic/indirect appeals in the child. This is the interesting facet or dimension of Das' expression. The portion of the letter of G.W. Prothero, a senior fellow of the King's College, written for James Cotton (brother of Sir Henry Cotton) dated 20 November, 1892 clearly indicates the motive of the editor/compiler here. It is quite clear from the extract that Sri Aurobindo was quite different and exceptionally talented one. His father had no knowledge about the change of his son's plan and opting another ship. He thought that his son died of with the sunken ship. A severe heart attack due to this took Aurobondo's father into the bed of death. By the way Aurobindo started a new life after the gap of fourteen years. Das describes it as 'the 
beginning of a new phase of life' of Sri Aurobindo. The philosophical matrix of the tone of Sri Das may be measured from the following few lines.

"Since he set foot on the Indian soil on the Apollo Bunder in Bombay, he began to have spiritual experiences, but these were not divorced from this world but had an inner and infinite bearing on it, such as a feeling of the Infinite Pervading material space and the Immanent inhabitant material objects and bodies. At the same time he found himself entering Supraphysical worlds and planes with influences and an effect from them upon the material plain." (Das (ed.), 1995: p. ii)

Many of the times it has been heard that Manoj Das is an advocate of Indian Philosophy, Indian Culture and Hinduism. It is also true from many angles. This can be concluded from the very first chapter ('Bhaarateeya Chetanaa Eka Sammilanee: Eka Sanlaapa') of the book 'Smrutira Pradeepa' which means 'The Lamp of the Memories'. It was an event of February, 2002 when he had gone to Neemrana. The discussions of Sri Das with the then Prime Minister Atal Bihari Vajpayee and previous PMs of India and eminent literary persons like Khuswant Singh, Ved Mehta, V.S. Naipul and Nayanthara Saighal (daughter of Bijaylaxmi Pandit) in this particular week gave him a different identity and even the writers like Paul Zacharia criticised Das for his 'active philosophical (philosophy of Hinduism and Hinduism centric) talk' that 'moved the entire conference' (Das, 2009, p. 17) that day.

Manoj Das has given a beautiful introduction to the compiled works of Sri Aurobindo named 'The Hour of God'. The name itself is philosophical and reflexive in many ways. The book has been published by Sahitya Akademi in 1995. The title of the introduction of Sri Das is 'Sri Aurobindo and His Works'.

Das' literature or commentary is purely based on the philosophical doctrines laid down by Sri Aurobindo. Manoj Das has focused on the philosophy of 'Yoga' and there remains a submerged vision for the human destiny through the evolutionary trends of time. We encounter various facets of his literature such as: the social and political thoughts, thoughts on literature, art and education and poetry. In many ways we encounter Sri Das as a 'searching fellow'. He is equally serious about the human evolution. If man has been developed out of monkey or amoeba or any primordial organism then what about the next state and stage of human being? What will be the evolutionary product of human being? This is the condition where a superman evolves. By the way, Manoj Das' specialty is also something else. Often he searchers the common and general things in human being as well as in the so called civilized society. He has examined well if we have left something significant in jungle where we have come from. However, in these ways he goes to search the unknown and unseen part of life. But the modus operandi of Das is very peculiar and special and that is: he often goes to a 'known part' from an 'unknown' one. This in fact reveals the reality and potency of human being. This is perhaps the mystery and miracle of human life and birth. Das has ever been tried to deal with these delicate and infinitesimal truth.

Manoj Das is typically unique in his each and every attempt. For example, in his 'Kathaa o Kaahaanee' (1971), we see total 54 short stories (in its ninth edition) where each one differs from the other in many respect. Sometime one is different and special in style and some other time it is unique in language.

He says about 'analogy', 'justice' and contextually uses the terms like 'uncertain duty', 'aftermath', 'methodically', 'eyewitness' etcetera (Das: 2005, p. 2-6) in his very first article 'The Sinister Twilights' of the book 'My Little India'. These terms conspicuously indicate and direct towards his philosophical attitude and modus operandi. Some captions given by Das may be cited here in this regard in the particular book. They are: 'Death after the Loveliest Sunset', 'A Domain Beyond God', 'In the Quest of the Mythical Forest', 'The Shadow of the Silent Forest', 'The Tragedy of Greatness', 'Rider of the Blue Horse', 'One and a Quarter of a Man', 'Imprints of Some Tender Palms', 'Legend of the Mysterious Fruit', 'The God-Souled Himalayas', 'On the Perfect Singer and His Perfect Listeners', 'The Fading Path to Liberations', 'A Midnight Rendezvous', 'The Forbidden Cave: The Nursery of the Great Epic', ' Farewell to the Workshop of Vyasa', A Drive with a Dialogue on Dreams', 'A Territory of Innocence', 'Denizens of Snow and Infinity', 'Footprints of the Enlightened One', 'The City Older than Time', 'In the Quest of the Lost Peacocks', 'A Tryst with the Unknown', 'A thousand Hidden Islands', 'Two lovers of the Lord', 'Is the Lord's Bliss Still Undisturbed?', 'In Search of an Evening Marked by a Lantern and Stars' and 'A Legend and an Illumination'. It will be too lengthy if one tries to uncover his philosophical treatments and perspectives one by one from his articles. Therefore, his own words from the 'preface' to this book may be taken into account of dissection/ autopsy and forensic test in order to confirm his philosophical temperament and introspection.

"There are many ways to look at India- rather many visions through which to experience the phenomenon that is India. [...] this author's vision of India has been often, if not always, coloured by his rustic emotions and nostalgia. May he suggest that he be spared of any scrutiny with any yardstick of history, for this work in an invitation to share, if you are in a leisurely mood, the author's impressions of places and people, as his mind and imagination recorded them over the years." (Das, 2005: p. vii)

He is quite philosophical and conscious about the history of India and the world at one hand and seriously aware about the individual as well as collective psychology at the other one. Another statement of Das makes his vision so crystalclear about the theme we discuss. He says-

"While the first few articles, on the Andamans are factual, 'dreams and romance' dominated the pieces on Rajasthan and the rest are a fusion of objective experiences and subjective reactions."(Das, 2005: p. viii)

The author is quite a serious reader. He has good dip in the ocean of Indian as well as Western philosophy. He is referring to Mark Twain's words. Mark Twin had a remark on the incredible vastness and depth of India in $19^{\text {th }}$ century. "Visions could also interspersed with one another while looking at India, as it happens in Mark Twain's summary of the country [...]", says Das. (Das, 2005: p. vi) Mark Twain says about India in his 'More Tramps Abroad' (1897) that-it is " the one land that all men desire to see, and having seen once, by even a glimpse, would not give that glimpse for shows of the rest of the globe combined." (Das, 2005: p. vi) 
India is such a magical land where the twigs of philosophy sprouts easily in the fertile cerebral ground/stems like Manoj Das. The land, water, spring and air of India make a simple person into poet and philosopher. This why it $\mathrm{s}$ believed to an incredible country. The scenes and the societal settings force people to search for the existence of self and all reasons behind the same.

Manoj Das is an incredible story teller but apart from this he has been established as a tremendous novelist of the time. His principal approach in this field is quite philosophical. It is quite crystal clear in the most famous novel 'Amruta Phala' (The Divine Fruit) and the recent novel 'Sesha Taantrikara Sandhaanare' (In the Search of the Last Tantric). His philosophical temperament is not at all less in his 'Aakaashara Isaaraa'. A line from the recent novel shows his attitude towards men and women and also towards the complexity of human behaviour. Ergo, he says,

"It is not easy to perceive into the human mind irrespective of sex, but it is harder to enlighten into the mind of self." (Das: 2018, p. 106)

This is one of the greatest philosophies of life that one must look into everything, every philosophy along with the beauty and loose faults of self. The literary message of Das is really praiseworthy and age-worthy in this contemporary context. Similarly, one must be very obvious and general in case of various cases / events of different sexes. However, Manoj Das has never been detached from the root of the great Indian tradition and codes of conduct of the Sanaatan Dharm. Therefore, perhaps, he has spoke about the concepts of rebirth and has strong believe in it. Very artistically, he has said that one cannot detach the concept and impact of rebirth from one's every day, hour, second and minute. Life is a continuous passage. We are just flowing in that designed passage. Our works and belief determines the nature of our path. He says-

"Since rebirth is not detached from my days and months of life, I don't feel bad or uncomfortable imagining these possibilities." (Das, 2018: p. 311)

Shri Das is often philosophical in his stamen and also in his fictional world. As if he means literature as a carrier of philosophy in order to sustain and strengthen life here after this life. This noble objective is keenly attached to the life and literature of this noble litterateur. Sometimes one may remark that Das is more a philosopher and less a story teller or litterateur. He is the person who reads the silence of a flower, fragrance of it and its colour, texture and its meaning and reason behind it. He searches for the cause of the causes. He believes in the paramount meta-cause of everything. Is not is spiritualism? Every beautiful creation is the consequence of beauty and pleasure of the almighty God and he is there underneath the beauty and strength and every good thing. That does not mean that the thing which seems bad to us is not created by us and is not followed by His pleasure. But it is very clear that we may not understand the entire spectra of motif of the creation of the thing. This entire world, this air, this wind, water, fire, soil, this vast sky and every dust and atom of it is well imagined and calculated and then only created by the paramount truth, the cause of all causes. He just says that one must search for this design and this pleasure in fact. Then only s/he can get the eternal and permanent pleasure out of this mundane creation. This is the way one can better his/her own life in this earthly and sorrowful world. Just one instance from his lines may substantiate the above lines. The line is like this-

"If you can taste the pleasure that the flower disseminates/ radiates in silence, the pleasure that lies underneath its creation, then you need not search any other pleasure in life."

Manoj Das has reached the beautiful level of philosophy where one can see oneself and smell the existence of self. This very important in one's life to examine and feel the eternal flow of oneself. It needs heavy and dense concentration. One can feel the inner self the inner person in any place, anywhere, anytime and in any condition. It is another pleasure of life. And surprising the method of feeling this is to feel lonely first and then s/he can be found with another self, the real self. This conversation between the outer and the inner self is the cause of the pleasure. It may be termed as meta-pleasure or spiritual pleasure and after this if someone searches the causes of all these things then s/he may get the heavenly pleasure or the para-pleasure or paraspiritual pleasure.

"I have my conception from my own experience that everybody of us was feeling lonely. As if I was feeling like a prisoner inside a mobile cellular jail with wheels although I was moving."

From this above line one can easily judge the height of Das' philosophy. He is a person who believes in the power of time. The time is really very powerful and the best example is the life of the story teller himself. His personal family life ruined in the tide of time. But he again became one of the great faces of entire Asia and the world. Time regulates us and our wishes and this time defines man properly. This time renames us and this time defames us. This time renames Ratnaakar to Vaalmiki and this time also renames Sidhharth to Gautam Budhha. And it the time which makes a person king and also brings the same person to the footpath with empty stomach and torn clothes and lacerated lot. Perhaps, therefore he has given extreme significance to time in many places. Here is an example where he has given a typical remark on time.

"The symbol of the deadly Time: minimize."(Das, 2018: p. 340)

Every creation of this earth is never meaningless and woman out of those creations is the most precious and priceless. Women have been depicted in many myths and books as the cause of ruins of great cities and prosperities. But here Das has just remarkably said that-

"Woman is the open or secret power of the unleashing and unbridled tussle for the victory of truth and eternal, both in the physical and eternal world." (Das, 2018: p. 379)

Now, with an example, we can find the standard of Shri Das how he can magnify and draw the beat by beat texture of truth, fate and the general reality on the canvas of spiritual reality. He is the seer of the great Nature and thus he tries restlessly the cause of the beauty of this heavenly earth. He goes beyond every humanly logic in order to attain and feel the existence of eternal and heavenly or celestial pulchritude. The extract is right below for view and in order to feel the texture of his talent. 
"Can a daughter of human being laugh like this? It was a handful of overflowing beauty of the Heaven. He, who is the architect of rainbow, he, who is the artist of sunset, who blooms thousands of flowers, only he can bloom the smile of that kind in the face of that girl." (Das, 2018: p. 98)

In fact, to look into the world of Manoj's Fiction is not at all a simple job as it needs intense investigation, elucidation, interrogation, theorization and the most significant thing is to philosophize. Right from the title, Das has started his delicate works with metaphysics. Manoj Das is primarily a successful short story teller. This is the primary reason for which we encounter him 'symbolic' in many ways, in many folds and in many layers. And this practice has well been reflected in each and every paragraph and from top to bottom of the novels. Aakaashara Isaaraa is also that kind of novel. That means, it is a novel of that height which has the potency to radiate the beauty of philosophy under the visor of symbolism

\section{The Very Other Dimension of Philosophy versus the Literature of Das}

The literature of Sri Das is quite refined and defined. It is due to the extra-ordinary personality of Das. Das possesses a binary personality about which earlier a brief discussion has been made. And here, this may be quoted that that other personality of Das remains alert and conscious when he takes dips in the world of aesthetics, philosophy, beauty and a particular theme of a literature. This second and undivided personality always brings him back to the surface of 'reality' (inner/outer) wherever and whenever he goes away from it. And it is true that the greatest philosophy over and above all the philosophies is the philosophy of life. And Manoj Das has quite significant and intimate relevance with this philosophy and only due to this we encounter various satires to the human attitudes, cultures, traditions, dogmas, doctrines, socio-cultural rituals, religions etcetera in different forces and frequencies. In a conversation (interview) he has countered a myth (societal belief) of undivided Koraput district. This particular myth has been collected by the veteran folklorist Verrier Elwin. The particular myth is based on the head shaving tradition of the women of the Bonda tribe of the undivided Koraput district. The other impact of the particular myth is the women of the tribe remain unclothed till now due to the belief of curse of Goddess Sita (A mythical story/belief during the exile of Ramachandra with his brother Laxman and beloved wife Sita). Manoj Das has experienced this from a conference of Folklorists of India from different states. (See 'Question answer with Manoj Das'(2015) edited by Samir Ranjan Das. P. 100-101) similar scenes may be judged in his work named 'The Submerged Valley'. There his inner personality which holds the flag of philosophy of reality is quite conscious about the colonial period of India and the mental condition thereon. Therefore, he has sketched a character like Saheb intentionally there. What about religious reliance, what about cultural credence, what about the personal persuasion and thriving, what about the existence of the visceral sentiment or vehemence of humanity or what about life- in each and every sphere as a conscious and committed writer his works have been proved seminal. In fact, he is a ground breaking writer of India whose works are not only philosophical by marrow but also formative and productive by nature contemporaneously. In an interaction said Das, "Society is not greater always than Literature." (Das (ed.), 2015, p.104-111) He has a personal believe on the unseen power of the Almighty. And this is restlessly affecting the whole universe and the cosmos of Das' literature. Our mind has a keen relation to that unseen but felt power. Therefore we need to cherish our inner Soul, spirit and mind (say willpower). What is this? Is this apart from the great Indian Upanishadic Philosophy? "Not at all", says the raconteur himself. He believes in the statement of a philosopher as he answered to a question Kamalakanta Pati in his interview. We may have the statement quoted here. "Someone for the philosophers had said, "It is only respect for which one does not need to try or work. That is increase of age."[...]." (Das (ed.), 2015: p. 89) Similarly, in an answer to the question of Abhay Diwedi during his first question of interview said Manoj Das, "An unseen evolutionary power is restlessly working underneath the elbow grease or the endeavour, behaviour and functioning of society, literature, various reinforcement of human being, institutions and organizations. If there was a premature society in the prehistoric era, it would have been in that form till date without the magnanimity of that power." (Das(ed.): 2015, p. 104) Further he says that "that faculty works inside the consciousness of human being. Due to that particular faculty we have bettered our society by dance, music, sculpture, art and architecture. It has induced and inspired us for literature, philosophy and science." (ibid, p. 104) It has further generated and engendered the spirit within to kindle the supra-natural quality inside us. This has made us able to trigger the conscience to determine and differentiate between the right and wrong. In this way this particular litterateur remains submerged in the matrix of philosophy partly being aware of reality. The post-independence Odia prose and fictions and particularly the short stories have shown their commitment and intensive attachment with the radical changes occurred in various dimensions of society like culture, politics, economic condition, societal structure, social values and most significantly the evolution of human mind. J.M. Mohanty therefore says-

"Next to poetry, the literary genre that emerged in richness and force in the post-independence years in Orissa was short story. Like poetry it grew from many sources spread to many channels. But more than poetry, and more eloquently, it got linked with the fast changing socio-political and cultural climate, and particularly with the shift from the village to the town, and from a primarily agricultural environment to an urban and industrial one. This had singular effect on human psychology and human attitudes, and the individual awareness and identity went through radical transformation. Whereas in poetry it was mainly a matter of individual perception and understanding, the expression of a probing mindset, in short story it took more concrete structure related to society and changing environment."(Mohanty, 2006: p. 588)

These commitments and resonances have well been reflected and refracted through the prism of Das' literature. Manoj Das is a remarkable writer in this period with regard to these themes and concepts. The socio-psychological x-ray pictures have been well studded in his literature. Many critics like J.M. Mohanty have accepted Das as "an exponent of Sri Aurobindo philosophy". (Mohanty, 2006: p. 611) Manoj Das is a veteran speaker of Indian culture and Oriental philosophy which is often embedded in the matrix of humanism. He has always emphasized the great Indian tradition and there he brings a new kind of radiation by his individual personal talent. He has well reflected the preindependence and post-independence Indian scenario. "[...] 
he believes that India has her specific characteristics too and an Indian writer, when guided by his spontaneous inspiration, is bound to breathe the Indian spirit into his writing." (1993: 06) Further, P. Raja says that, "Manoj is an admirer of T.S. Eliot's theory on 'Tradition and Individual Talent'. According to him the meeting point of these two elements is as subtle and submerged as the meeting point of the horizon at the ocean's blue with the sky's. he says in the same interview cited above, "when an Indian writer in naturally Indian, his Indianness is hardly pronounced, but what becomes grotesquely pronounced is when an Indian writer makes a conscious effort to highlight his Indianness or does the opposite-tries to consciously cultivate a stance that should appear dazzlingly different from the traditional writing"." (Raja, 1993: 06) One can easily mark with minute observation that how satirically Manoj Das has sketched the clash between two serious classes (people with traditional values and the people with changing values) of societal psychology. The story of 'Mystery of the Missing Cap' may be cited as an instance in this particular case. In his world of literature we can find many worlds like the world which is made of Indian sensibility, Indian Psychology, Transcendentalism or transcendental attitude, humanism, humanitarian philosophy, death secret and the Hindu and universal culture of death, different psychological episodes, child psychology, women psychology, male psychology, psychology of different socio-economic, political and sociopsychological classes. He has revealed many secret of human life. And like Fakir Mohan Senapati he has not left the tadkaa of humour anywhere. And it is one of the specialties of Das that he is the worthy descendant of Senapati for two things mainly and those are: deal with real and raw life forms of Odisha and use of mild humour in it. However, it has given him a special distinction in the firmament of Indian and Asian literature.

\section{Conclusion}

On the basis of the discussions above and analysis of texts and contexts of his literature at personal level, it may firmly be concluded that the literature of the literature of Sri Das is not at all different from the literary matrix of philosophy. We encounter both the philosophies: the East and the West Especially, he has gradually been influenced by the philosophical doctrines of Sri Aurobindo. The writer has tried to establish the supra-mental philosophy in the head, heart and spirit of the reader as well as in the entire society. Sometimes it looks surreal but in fact it is much real than common reality. Another major aspect of his literary approach is the psychological dimension which covers the psychology of the involved character as well as of the readers. In short, he knows the science and art of tracking, understanding and arresting the psychology of the direct characters (readers) and indirect characters. Another thing with regard to this phenomenon is his ability to convince and kidnap the readers' mind magically with his literary style and approach. In his world of fiction and short story he is quite conscious about different types of psychologies, i.e. Child Psychology [Shesha Basantara Chithi (The Last Letter of Spring)], Woman Psychology [Aakaashara Isaaraa (Sign of Sky)], Male Psychology [Aaranyaka, Aakaashara Isaaraa (Sign of Sky),Bhola Grandpa and the Tiger, Shesha
Taantrikara Sandhaanare (In Search of the Last Tantric)], Societal Psychology [Laxmira Abhisaara (Adventure of Laxmi), Aneka Smitahasa (Many Smiles), Bhootunee Eka Bidaaya (A Farewell to the Lady Ghost), Byaaghraarohana (Tiger-Ridding)], Institutional Psychology [The Submerged Valley, Amruta Phala (The Divine Fruit), Aakashara Isaaraa (Sign of Sky), Laxmira Abhisaara (Laxmi's Adventure)] and many other types of Psychologies. Sometimes he has shown the animal psychology in his writing but in fact it could be said that those are the personal cognition corner of the writer himself. However, from the above discussions we may firm draw a conclusion that the literature of Professor Sri Manoj Das has created a triangular aqueduct between Literature, Philosophy and Psychology and this is almost his unique capacity which makes him sui generis from among the other contemporary writers. . His consciousness about history, psychology and philosophy makes his literature more special.

\section{Reference}

[1] Bandyopadhyay, Krishna, (2005). Heidegger and Kant on the Problem of Metaphysics. College Street, Kolkata: Progressive Publishers.

[2] Das, Chittaranjan. (1982). A Glimpse into Oriya Literature. Bhubaneswar: Orissa Sahitya Akademi.

[3] Das, Manoj (ed.). (1995). The Hour of God. New Delhi: Sahitya Akademi.

[4] Das, Manoj. (1995). Mystery of the Missing Cap and Other Stories. New Delhi: Sahitya Akademi.

[5] Das, Manoj. (2005). My Little India. New Delhi: NBT.

[6] Das, Manoj. (2009). Smrutira Pradeepa (Lamp of Memory). Cuttack: Jagannath Rath Publisher and Bookseller.

[7] Das, Manoj. (2018). Shesha Taantrikara Sandhaanare (In the Search of the Last Tantric). Cuttack: Jagannath Rath Publishers and Bookseller.

[8] Das, Samir Ranjan(ed.). (2015). Manoj Dasnka Saha Prashnottara (An Interview with Manoj Das). Cuttack: Jagannath Rath Publisher and Bookseller.

[9] Kristeva, Julia. (2000). The Sense and Nonsense of Revolt. Trans. Jeanine Hermann. New York: Columbia University Press. (French Original: Kristeva, J. (1996). Sens et non-sens de la revolte. Paris: Fayard.)

[10] Mahapatra, Sitakant. (1977). "Connecting Everything to Everything- Landmarks in Post-Independence Oriya Literature" In: Sidelights on History and Culture of Orissa(ed.). Professor M.N. Das. Cuttack: Vidyapuri.

[11] Mohanty, J.M. (2006). History of Oriya Literature. Bhubaneswar: Vidya.

[12] Raja, P. (1993). Many Worlds of Manoj Das. Delhi: B.R. Publishing Corporation.

[13] Solomon, R. C. ,(1972). From Rationalism to Existentialism. New York: Harper and Row Publishers., San Fransisco, London: Evanston. 